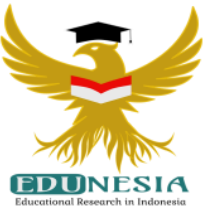

\title{
Correlation Self-Efficacy and Adversity Quotient of Students at SMK Muhammadiyah 2 Wedi Klaten
}

\section{Luthfi Ismawati ${ }^{1}$; Isnanita Noviya Andriyani ${ }^{2}$}

\author{
1,2Fakultas Ushuluddin dan Dakwah, UIN Raden Mas Said Surakarta, Indonesia
}

${ }^{1}$ Corresponding Email: luthfiismawati12@gmail.com, Phone Number: 0896 xxxx xxxx

\author{
Article History: \\ Received: Nov 18, 2021 \\ Revised: Jan 05, 2022 \\ Accepted: Jan 09, 2022 \\ Online First: Jan 15, 2022
}

\section{Keywords:}

Adversity Quotient,

Self Efficacy,

SMK Muhammadiyah.

\section{Kata Kunci:}

Daya Juang,

Keyakinan Diri,

SMK Muhammadiyah.

\section{How to cite: \\ Ismawati, L., \& Andriyani. I.N. (2022). Correlation Self-Efficacy and Adversity Quotient of Students at SMK Muhammadiyah 2 Wedi Klaten. Edunesia: Jurnal Ilmiah Pendidikan, 3 (1): 78-88.}

This is an open access article under the $C C-B Y-N C-N D$ license

\begin{abstract}
This study aims to determine whether there is a correlation between self-efficacy and adversity quotient for students of SMK Muhammadiyah 2 Wedi Klaten. This type of research uses quantitative research methods with a correlational approach. Sampling methods using simple random sampling with data collection techniques in the form of a scale. The research subjects were 70 students from class XI of SMK Muhammadiyah 2 Wedi, Klaten. The results obtained correlation analysis $\left(\mathrm{r}_{\mathrm{xy}}\right)$ of 0.708 with a p-value 0.000 that is lower than 0.05 , meaning that there is a significant positive correlation between self-efficacy and the student's adversity quotient. This can indicate that the higher the student's selfefficacy, higher the adversity quotient of the student, then Ho is rejected and $\mathrm{Ha}$ is accepted. Self efficacy and adversity quotient in students of SMK Muhammadiyah 2 Wedi, Klaten are classified as moderate. The coefficient of determination $\left(\mathrm{R}^{2}\right)$ of the correlation is 0.724 , meaning that self-efficacy contributes effectively to the adversity quotient by $72 \%$, which means there are $28 \%$ of the other factors that affect students adversity quotient.
\end{abstract}

Abstrak: Penelitian ini bertujuan untuk mengetahui ada tidaknya hubungan antara self efficacy dengan adversity quotient siswa SMK Muhammadiyah 2 Wedi Klaten. Jenis penelitian ini menggunakan metode penelitian kuantitatif dengan pendekatan korelasional. Pengambilan sampel menggunakan simple random sampling dengan teknik pengumpulan data berupa skala. Subjek penelitian sebanyak 70 siswa dari kelas XI SMK Muhammadiyah 2 Wedi, Klaten. Hasil penelitian didapatkan analisis korelasi $\left(\mathrm{r}_{\mathrm{xy}}\right)$ sebesar 0,708 dengan p-value $0,000<0,05$ artinya terdapat hubungan positif yang signifikan antara self efficacy dengan adversity quotient siswa. Hal itu dapat menunjukkan bahwa semakin tinggi self efficacy siswa maka semakin tinggi pula adversity quotient yang dimiliki siswa, maka Ho ditolak dan Ha diterima. Self efficacy dan adversity quotient pada siswa SMK Muhammadiyah 2 Wedi, Klaten tergolong sedang. Adapun koefisien determinasi $\left(\mathrm{R}^{2}\right)$ dari korelasi tersebut sebesar 0,724, artinya self efficacy memberikan sumbangan efektif terhadap adversity quotient sebesar $72 \%$ yang berarti masih terdapat $28 \%$ dari faktor lain yang mempengaruhi adversity quotient siswa. 


\section{A. Introduction}

Adolescence is the most important period in the life span, where individuals experience a transition period from children to adults. During this transition period, individuals experience various changes, including cognitive changes, physiological changes, and socio-emotional changes. Erikson (in Santrock, 2013) Adolescence is a time when individuals are faced with the challenge of discovering who they are, how they will be, and which direction they want to take in life.

According to the age range division proposed by Hurlock (2017) a person can be said to be a teenager when he is 13-18 years old. Vocational High School students are included in the adolescent age. Adolescence is the best period for learning, because at this time individuals reach physical and spiritual maturity as a whole so that they are able to learn optimally. At this time, teenagers also learn a lot about everything due to the great curiosity that exists in them. Learning activities are the most basic activities for students, but each student's learning activities do not always run smoothly. Many problems that must be faced by teenagers related to education.

The adolescent phase is preceded by the emergence of strong self-esteem, strong expression, and high courage. Therefore those who are in this phase often make noise, disturbing chaos. Usually in a noisy and excessive atmosphere of a physical nature, it is more common in boys. Girls are more into the expression bitchy, irritable, and sulky. Physical strength and greatness are often the main concern, so many teenagers who want to be famous in terms of physical strength are admired and appreciated. Meanwhile, in women the desire to get appreciation and attention is on the appearance of themselves with excessive makeup. They are easy to fall into a competitive atmosphere (Diananda, 2019).

Vocational High School (SMK) is a vocational school that equips students with special skills to prepare superior resources to meet the demands of the work environment. In vocational education, students are also given formal education materials such as regular high school (SMA). However, the portion of the lessons provided is adjusted to the vocational and practical material. Practices are held to hone students' skills in a real and direct manner. Practical learning is also more important because students are required to think and act simultaneously (Depdikbud, 2003).

Adversity quotient is an individual's ability to observe and manage difficulties with their intelligence so that it becomes a challenge to solve (Stoltz, 2018). Phoolka and Navjot (2012), fighting power is a tool to predict a person's success in facing difficulties. Aziz (in Wardani \& Saidiyah, 2016) someone who has high fighting power will try to remove the obstacles that prevent him from achieving success. The success of students in learning is influenced by how students overcome existing difficulties. Everyone's way of dealing with adversity is different.

Likewise, the level of intelligence of a person is different. Intelligence in the face of one type of adversity is the adversity quotient. Adversity quotient is a person's intelligence in overcoming every difficult situation that arises. Adversity quotient is often associated with fighting power to fight adversity. Adversity quotient is considered to be very supportive of 
student success in improving the quality and achievement of learning. Students who have good adversity quotient will be better able to overcome the difficulties they are facing. Students with low adversity quotient tend to perceive difficulties as a barrier to struggle and cause the quality of student achievement to be low (Hidayat \& Sariningsih, 2018).

Adversity quotient or fighting power is an important understanding of what is needed to achieve success. Individual success or failure in life is determined by adversity intelligence. Adversity quotient can tell the extent to which individuals are able to survive and overcome the difficulties they face. Adversity quotient can distinguish individuals who are able to overcome difficulties and those who are not able to overcome difficulties. Adversity quotient can also assess individuals who will meet expectations and who will fail to meet expectations, and are able to determine individuals who will give up and who will survive in difficult situations (Nurhayati \& Fajrianti, 2015).

Students who have a good adversity quotient will be able to withstand complex questions that require analysis. On the other hand, students with low adversity quotient will easily get stressed and show an unenthusiastic attitude during learning and easily give up and despair. adversity quotient is divided into 3 parts, namely quitters, campers, and climbers (Purwasih, 2019). Students who have the type of quitters will easily despair and stop while working on the questions. These students give up easily, tend to be passive, and have low motivation to solve problems. Students campers try to solve the existing problems and try to solve them. The efforts that have been made by the campers have not reached the peak of success and are easily satisfied with the success they have achieved. They are still trying to fulfill the needs of security and security as well as togetherness. Students who climbers type are students who always try to reach the peak of success and have a strong desire to try to solve problems. Always motivate him to stay passionate about achieving his dreams and desires. Climbers will try to achieve success regardless of background, profits, losses, bad luck, and good luck (Purwasih, 2019).

In the context of education, students must be able to overcome obstacles or failures to become opportunities and challenges for them to get the goals they want to achieve. For this reason, performance is needed for the adversity quotient as the intelligence behind success. Stoltz (2018) one of the factors of the adversity quotient is belief. Confidence in one's own abilities can influence a person in dealing with a problem and help someone in achieving the desired goal. Students who have confidence that they will be able to face and overcome problems that become obstacles to success for themselves, confidence in their abilities can also be called self-efficacy (Azzura, 2017).

Bandura (1997), says that self-efficacy is a perception of oneself to see how capable oneself can function in certain situations. Alwisol (2018), self-efficacy is a self-assessment, whether oneself is able to do something well or badly, right or wrong, can or cannot do something according to what is required. Gibson et al., (in Saidah \& Aulia, 2014), selfefficacy is the belief that a person is able to perform well in certain situations. Santrock (in Triyono \& Rifai, 2018) defines self-efficacy as the belief held by an individual that he or she is able to do or complete a task or job and master the situation and give positive results. 
Self-efficacy is self-confidence in dealing with the task at hand. Various studies also show that self-efficacy has an effect on motivation, tenacity, and learning achievement. Individuals who have low self-efficacy feel less confident that they can complete tasks well. So, they choose to avoid the task. The low self-efficacy is not only experienced by individuals who do not have the ability to learn, but can also be experienced by gifted individuals (Utami, 2013).

Self-efficacy is a belief in one's ability to organize and carry out a series of actions that are considered necessary. So as to achieve a result as expected. Among the effects of selfefficacy is a form of self-evaluation related to one's perception of one's competence and ability to complete certain tasks. Self-efficacy is a person's evaluation of his ability or competence in completing tasks, achieving goals, and overcoming obstacles. Self-efficacy is a concept to categorize parts of a broader theory about spirit and ways of thinking. Selfefficacy is an assessment of the specific content of competence in the formation of special tasks which include the ability to do something in different situations (Adiputra, 2015).

Self efficacy is one of the important factors in determining a person's achievement, especially in carrying out tasks. Self-efficacy has a positive, mutually supportive correlation. If a student has good problem-solving skills, then a student also has good self-efficacy. With high self-efficacy, in general a student will find it easier and succeed in exceeding the practice questions given to him, so that the final result of the learning is reflected in his academic achievement (Jatisunda, 2017).

Students with strong self-efficacy will have motivation, courage, and perseverance in carrying out the given task. Students with low self-efficacy will distance themselves from difficult tasks and quickly give up when faced with obstacles. This is indicated by the behavior of giving up when it is difficult to solve the problems at hand. This behavior also appears when students get information about a material. The material is difficult so that students tend not to believe that they can solve problems related to these problems. As a result, students cannot achieve learning success in learning, even though student abilities can be formed through the formation of good self-efficacy (Alifia \& Rakhmawati, 2018).

Students who get high scores in solving problems will have high self-confidence as well. The success of students in achieving high marks is due to their belief and active effort in learning. Self-efficacy determines how much effort students will make and how long students can persist in overcoming obstacles. As a result, self-efficacy also affects the achievement of learning achievement. The more confident students are in their abilities, the better their decision-making abilities will be. Self-efficacy plays an important role for students in solving existing problems (Putra et al., 2018).

Self-efficacy is an individual's ability to be influenced by the level of ability and skills possessed. Individuals who are confident will always believe in every action they will do. Feel free to do things according to his wishes and be responsible for his actions. These conditions can be a spirit in facilitating the learning process. Feelings of inferiority or shame are obstacles for a student in the learning process (Oktariani, 2018). 
Someone who has high self-efficacy will have a desire to increase his experience and knowledge in many fields, never give up, work hard, and be tenacious in improving his business. Positive behavior carried out by individuals who have self-efficacy highwill increase individual intelligence in solving the difficulties they face (adversity quotient). Someone who has self-efficacy highwill increase their motivation to keep trying to achieve success.

From the results of observations made by researchers at SMK Muhammadiyah 2 Wedi. The results of the initial questionnaire filled out by 90 students showed that there was a gap in the level of self-efficacy between groups of students with one another. Likewise, the adversity quotient is quite different. This makes researchers interested in surmising whether there is a correlation between self efficacy so that it can affect adversity quotient students'. And vice versa, is there a correlation between self-efficacy so that it can affect adversity quotient students'. Researchers conducted a study to determine the correlation between selfefficacy and adversity quotient students of SMK Muhammadiyah 2 Wedi, Klaten.

\section{B. Method}

Researchers use quantitative research methods with a correlational approach. Azwar (2017) qualitative method is a research procedure that emphasizes its analysis on data in the form of numbers, collected through measurement procedures and processed by statistical analysis methods. The correlational approach is an approach that aims to determine the strength and direction of the correlation on research variables (Azwar, 2017).

The subjects of this study were students of SMK Muhammadiyah 2 Wedi Klaten class XI, totaling 70 students. The research sampling method was simple random sampling. Simple random sampling is a sampling technique by taking randomly sampled members from the population without paying attention to the strata that exist in the population (Sugiyono, 2018).

Data collection in this study used a psychological scale as a primary data collection tool. Psychological scale is a measurement instrument to identify human psychological constructs. The self-efficacy variable was measured using the self efficacy scale compiled by the researcher with five expert judgments and the variable was the adversity quotient measured using the scale adversity quotient compiled by the researcher with five expert judgments. The type of scale used by the researcher is a Likerts' scale, which is a scale used to measure attitudes, opinions, and perceptions of a person or group of people about social phenomena. The Likerts' scale describes the variables to be measured into variable indicators. The variable indicator is used as a starting point for compiling instrument items which can be in the form of statements or questions (Sugiyono, 2017). In addition, researchers also use documentation data from schools to serve as secondary research data.

Prior to data analysis or hypothesis test, the validity test, reliability test, normality test, and linearity test are first carried out. Test the validity of this study using the content validity test and try out. On content validity, the researcher uses 5 professional judgments as assessors of the instruments to be used for data collection. After that, the researcher did a 
try out (trial) to analyze the scale of the study, to find out the weaknesses and shortcomings that might occur in the items on the scale, both in terms of editorials, available alternative answers, and in scale statements. The trial was carried out on subjects that were not included in the research sample, but had the same characteristics as the research sample (Sugiyono, 2018). The subjects of the scale trial were 90 students class X of SMK Muhammadiyah 2 Wedi. The research reliability test used Cronbach' alpha from the SPSS version 17. This study used the Kolmogorov-Smirnov normality test, which is the normality test by paying attention to the level of conformity between certain theoretical distributions. Furthermore, the linearity test was carried out using the SPSS version 17, namely the test for linearity with a significance level of 0,05 .

The data analysis method in this study used the person bivariate product moment correlation analysis from the SPSS version 17. The pearson bivariate product moment correlation was used to test the hypothesis of the data in the form of intervals or ratios. Ratio is a number that shows the mathematical correlation between one number and another. Then correlational research uses empirical mean, hypothetical mean, and categorization to describe research subjects with the help of SPSS version 17 program. These measurements are useful for seeing the state of the subject in determining the level of variables owned by research subjects.

\section{Result and Discussion}

\section{Results}

Hypothesis testing in this study used the Bivariate Correlation Test (Pearson) product moment.

Table 1. Correlation test results

\begin{tabular}{llll}
\hline Self Efficacy & Pearson Correlation & 1 & $0.708^{* *}$ \\
& Sig. (2-tailed) & & 0.000 \\
& $\mathrm{~N}$ & 70 & 70 \\
\hline Adversity Qoutient & Pearson Correlation & $0.708^{* *}$ & 1 \\
& Sig. (2-tailed) & 0.000 & \\
& $\mathrm{~N}$ & 70 & 70 \\
\hline **. Correlation is significant at the 0.01 level (2-tailed). \\
\hline
\end{tabular}

The significance value of the Pearson correlation (2-tailed) is 0.708 with a p-value of $0.000(0.00<0.05)$, so the results of the correlation analysis between variables indicate that the data has a positive. 
Table 2. Description of data

\begin{tabular}{|c|c|c|c|c|c|c|c|c|c|}
\hline \multirow{3}{*}{ Scale } & \multirow{3}{*}{$\mathbf{N}$} & \multirow{2}{*}{\multicolumn{2}{|c|}{ Hypothetical }} & \multirow{3}{*}{ Mean } & \multirow{3}{*}{ SD } & \multicolumn{2}{|c|}{ Empirical } & \multirow{3}{*}{ Mean } & \multirow{3}{*}{ SD } \\
\hline & & & & & & & & & \\
\hline & & Min & $\operatorname{Max}$ & & & Min & $\operatorname{Max}$ & & \\
\hline Self Efficacy & 70 & 39 & 195 & 117.00 & 78.563 & 105 & 178 & 142.942 & 20.380 \\
\hline $\begin{array}{l}\text { Adversity } \\
\text { Quotient }\end{array}$ & 70 & 37 & 185 & 111.00 & 74.534 & 99 & 157 & 126.357 & 15.076 \\
\hline
\end{tabular}

The empirical mean of the self-efficacy scale is 142,942 , which is greater than the hypothetical mean of 78,563 . It can be said that the subject has self-efficacy above the average hypothesis. The empirical mean of the adversity quotient scale is 126,357 , which is greater than the hypothetical mean of 74.534. It can be said that the subject has an adversity quotient above the average hypothesis.

Table 3. Self efficacy scale categorization

\begin{tabular}{|c|c|c|c|c|c|}
\hline \multirow[b]{2}{*}{ SD } & \multirow[b]{2}{*}{ Score } & \multirow[b]{2}{*}{ Category } & \multicolumn{2}{|c|}{ Subject } & \multirow{2}{*}{$\begin{array}{c}\text { Empirical } \\
\text { Mean }\end{array}$} \\
\hline & & & Freq. & Percentage & \\
\hline$(M+S D) \geq X$ & $x \geq 163$ & High & 12 & $17,14 \%$ & \multirow{3}{*}{142,942} \\
\hline $\begin{array}{c}(\mathrm{M}-\mathrm{SD}) \leq \\
\mathrm{X}<(\mathrm{M}+\mathrm{SD})\end{array}$ & $122 \leq X<163$ & Medium & 47 & $67,14 \%$ & \\
\hline $\mathrm{X}<(\mathrm{M}-\mathrm{SD})$ & $x<122$ & Low & 11 & $15,71 \%$ & \\
\hline
\end{tabular}

From the self-efficacy scale category as shown in the table, it can be concluded that $17.14 \%$ of students of SMK Muhammadiyah 2 Wedi Klaten have high self-efficacy, $67.14 \%$ of students have moderate self-efficacy, and $15.71 \%$ of students have self-efficacy. So in general, students of SMK Muhammadiyah 2 Wedi Klaten have moderate self-efficacy.

Table 4. Adversity quotient scale categorization

\begin{tabular}{|c|c|c|c|c|c|}
\hline \multirow[b]{2}{*}{ SD } & \multirow[b]{2}{*}{ Score } & \multirow[b]{2}{*}{ Category } & \multicolumn{2}{|c|}{ Subject } & \multirow[b]{2}{*}{ Empirical Mean } \\
\hline & & & Freq. & Percentage & \\
\hline$(\mathrm{M}+\mathrm{SD}) \geq \mathrm{X}$ & $X \geq 141$ & High & 29 & $41,42 \%$ & \multirow{3}{*}{126,357} \\
\hline$(\mathrm{M}-\mathrm{SD}) \leq \mathrm{X}<(\mathrm{M}+\mathrm{SD})$ & $111 \leq X<141$ & Medium & 36 & $51,42 \%$ & \\
\hline $\mathrm{X}<(\mathrm{M}-\mathrm{SD})$ & $X<111$ & Low & 5 & $7,14 \%$ & \\
\hline
\end{tabular}

From the adversity quotient scale category as shown in the table 4, it can be concluded that $41.42 \%$ of SMK Muhammadiyah 2 Wedi Klaten students have a high adversity quotient, $51.42 \%$ of students have a moderate adversity quotient, and $7.14 \%$ of students have an 
adversity quotient. The low one. So in general, students of SMK Muhammadiyah 2 Wedi Klaten have a moderate adversity quotient.

Table 5. Strength test of the correlation

\begin{tabular}{rcrrr}
\hline \multicolumn{5}{c}{ Measures of Association } \\
\hline & $\mathrm{R}$ & $\mathrm{R}$ Squared & Eta & Eta Squared \\
\hline Self Efficacy * Adversity Quotient & 0.708 & 0.501 & 0.851 & $\mathbf{0 . 7 2 4}$ \\
\hline
\end{tabular}

The significance value of eta squared is 0,724 . With a level of $5 \%$, the results of the analysis show that the data has a significant correlation.

\section{Conclusion}

Based on the results of the hypothesis test, the hypothesis which states that there is a positive correlation between self-efficacy and adversity quotient at SMK Muhammadiyah 2 Wedi Klaten students is accepted. This can be seen from the $r$-value $x y$ equal to 0,708 with a $p$ value equal to 0.000 where the $p$-value $<0,05$. That indicates a significant positive correlation between self-efficacy and adversity quotient. Higher the self-efficacy, higher the adversity quotient. Vice versa, lower the self-efficacy, lower the adversity quotient.

The correlation between self-efficacy and adversity quotient results in accordance with what was stated by Bandura (1997), that self-efficacy has a large effect on a person's behavior in dealing with difficulties. The behavior of someone who has confidence in good selfefficacy will later be able to respond to challenges and anticipate situations appropriately. A person's accuracy when facing a problem can be said that the person has adversity intelligence. Adversity intelligence is a person's ability to overcome difficulties so that these obstacles can be used as challenges to be resolved in order to achieve what is desired.

Self-efficacy plays an important role in the formation of adversity quotient students'. self-efficacy Students Can be seen from three aspects, namely level, generality, and strength. The level aspect can be measured by how high the level of a task or challenge is, which results in higher demands self-efficacy. The level of a high task is then not matched by a strong belief in the student, then the student will feel that the task at hand cannot be completed.

In addition to requiring sufficient knowledge, students also need strong selfconfidence when facing difficult tasks. Students with high self-confidence will trigger students to try to solve and overcome the problems and challenges they face. It can be said that the greater the effort made by students, the greater the adversity quotient of vocational high school students. This is because they are trying to survive and solve existing problems, tasks, and challenges (Stoltz, 2018). This shows that self-efficacy has an effect on contributing to the adversity quotient in facing increasingly complex challenges.

The aspect of generality can be seen from whether students have strong selfconfidence in many situations or only in certain situations (Bandura, 1997). When students have high self-efficacy in various situations, these students will not feel surprised and afraid 
in dealing with situations that they are not accustomed to. If students have a high generality aspect, they will have strong self-confidence in various situations. This makes it easier for students to face assignments in various conditions and unfavorable environments, because they are able to see themselves confidently that challenges can be solved in various situations. Confidence to be able to face problems will encourage students to have an adversity quotient in all problems even though there are many obstacles that get in the way.

The last aspect is strength, which can be seen from the way students can survive in the face of a challenge. Students have a good strength aspect, so they will survive in the face of problems. Students also tend not to give up easily, are optimistic, and make the task a challenge to complete. According to Stoltz's (2018) statement that someone who has a high adversity quotient will be optimistic. An optimistic person will believe that adversity is a challenge that can be solved. Individuals who have a high adversity quotient will be strong and able to overcome difficulties in sharing situations. Adversity quotient adequate accompanied by high self-confidence will lead to success (Wijaya, 2019)

\section{References}

Adiputra, S. (2015). Keterkaitan self efficacy dan self esteem terhadap prestasi belajar mahasiswa. Jurnal Fokus Konseling, 1(2).

Alifia, N. N., \& Rakhmawati, I. A. (2018). Kajian kemampuan self-efficacy matematis siswa dalam pemecahan masalah matematika. Jurnal Pembelajaran Matematika, 5(1).

Alwisol. (2018). Psikologi kepribadian edisi revisi. Malang: Universitas Muhammadiyah Malang.

Aulia, Vivi. (2016). Kajian tentang kesiapan siswa SMKN dalam penguasaan pemahaman teks bahasa inggris berbasis pendidikan karakter lahan basah (wetland) sebagai local wisdom di kota Banjarmasin. Prosiding Seminar Nasional Lahan Basah, Banjarmasin, 3, 1094-1101.

Azwar, Saifuddin. (2017). Metodologi Penelitian Psikologi. Yogyakarta: Pustaka Pelajar.

Azzura, L. (2017). Hubungan Antara Self Efficacy Dengan Adversity. 1-12.

Bandura, A. (1997). Self efficacy, The Exercise of Control. New York, NY: W. H. Freeman

Depdikbud. (2003). Undang-undang RI Nomor 20, Tahun 2003, tentang Sistem Pendidikan Nasional.

Diananda, A. (2019). Psikologi remaja dan permasalahannya. ISTIGHNA: Jurnal Pendidikan dan Pemikiran Islam, 1(1), 116-133. 
Hidayat, W., \& Sariningsih, R. (2018). Kemampuan pemecahan masalah matematis dan adversity quotient siswa SMP melalui pembelajaran open ended. JNPM (Jurnal Nasional Pendidikan Matematika), 2(1), 109-118.

Hurlock, EB. (2017). Psikologi Perkembangan: Suatu Pendekatan Sepanjang Rentang Kehidupan. Edisi Kelima. Jakarta: Penerbit Erlangga.

Jatisunda, M. G. (2017). Hubungan self-efficacy siswa SMP dengan kemampuan pemecahan masalah matematis. Jurnal Theorems, 1(2), 301745.

Maryam, S. (2015). Self efficacy anak didik pemasyarakatan di Lapas anak kelas IIA Blitar (Doctoral dissertation, Universitas Islam Negeri Maulana Malik Ibrahim).

Nurhayati, \& Fajrianti, N. (2015). Pengaruh Adversity Quotient (AQ) Dan Motivasi Berprestasi Terhadap Prestasi Belajar Matematika. Jurnal Formatif, 3(1), 72-77.

Oktariani, O. (2018). Peranan self efficacy dalam meningkatkan prestasi belajar siswa. Jurnal Psikologi Kognisi, 3(1), 45-54.

Phoolka, E. R. S., \& N. K. (2012). Adversity Quotient: A New Paradigm to Explore. International ournal of Contemporary Business Studies, 3(4), (pp 67-78).

Prianto, S. I. (2017). Pengaruh kecerdasan emosional dan tingkat daya juang terhadap prestasi belajar IPS pada siswa SMA di Jakarta Selatan tahun ajaran 2014/2015. Research and Development Journal of Education, 3(2).

Purwasih, R. (2019). Kemampuan berpikir kreatif matematis siswa SMP dalam menyelesaikan soal pemecahan masalah ditinjau dari adversity quotient tipe climber. AKSIOMA: Jurnal Program Studi Pendidikan Matematika, 8(2), 323-332.

Putra, H. D., Putri, A., Lathifah, A. N., \& Mustika, C. Z. (2018). Kemampuan Mengidentifikasi Kecukupan Data pada Masalah Matematika dan Self-Efficacy Siswa MTs. JNPM (Jurnal Nasional Pendidikan Matematika), 2(1), 48-61.

Saidah, S., \& Aulia, L. A. A. (2014). Hubungan self efficacy dengan adversity quotient (AQ). Jurnal Psikologi: Jurnal Ilmiah Fakultas Psikologi Universitas Yudharta Pasuruan, 2(2), 5461.

Santrock, J. W. (2013). Life Span Development. Jilid II. Jakarta: Penerbit Erlangga.

Stoltz, P. G. (2018). Adversity Quotient Mengubah Hambatan Menjadi Peluang. Grasindo.

Sugiyono, S. (2017). Statistika Untuk Penelitian. Alfabeta.

Sugiyono, S. (2018). Metode Penelitian Kuantitatif dan R \& D. PT. Alfabeta.

Triyono, T. \& Ekhsan Rifai, M. (2018). Efikasi Diri dan Regulasi Emosi dalam mengatasi Prokrastinasi Akademik. Surakarta: Sindunata. 
Utami. (2013). Self efficacy dengan kesiapan kerja siswa sekolah menengah kejuruan. Jurnal Ilmiah Psikologi Terapan, 1(1), 40-52.

Utami, L. H., \& Nurjati, L. (2017). Hubungan Self-Efficacy , Belief dan Motivasi dengan Kecemasan Mahasiswa dalam Pembelajaran Bahasa Inggris. Jurnal Ilmiah Psikologi, 4, 205-218.

Wardani, W. S. K., \& Saidiyah, S. (2016). Daya Juang Mahasiswa Asing. Psympathic: Jurnal Ilmiah Psikologi, 3(2), 213-224.

Wijaya, H. A. (2019). Hubungan Antara Self Efficacy Dengan Adversity Quotient Pada Mahasiswa Perantauan (Doctoral dissertation, UNIKA Soegijapranata Semarang). 